\title{
The influence of perceived uncertainty on entrepreneurial action in emerging renewable energy technology; biomass gasification projects in the Netherlands
}

\author{
Ineke S.M. Meijer ${ }^{\mathrm{a}, \mathrm{b}, *}$, Marko P. Hekkert ${ }^{\mathrm{a}}$, Joop F.M. Koppenjan ${ }^{\mathrm{b}}$ \\ ${ }^{a}$ Department of Innovation Studies, Copernicus Institute for Sustainable Development and Innovation, Utrecht University, PO Box 80115, \\ 3508 TC Utrecht, The Netherlands \\ ${ }^{\mathrm{b}}$ Department of Policy, Organisation \& Management, Delft University of Technology, PO Box 5015, 2600 GA Delft, The Netherlands
}

Received 23 April 2007; accepted 12 July 2007

Available online 24 August 2007

\begin{abstract}
Emerging renewable energy technologies cannot break through without the involvement of entrepreneurs who dare to take action amidst uncertainty. The uncertainties that the entrepreneurs involved perceive will greatly affect their innovation decisions and can prevent them from engaging in innovation projects aimed at developing and implementing emerging renewable energy technologies. This article analyzes how perceived uncertainties and motivation influence an entrepreneur's decision to act, using empirical data on biomass gasification projects in the Netherlands. Our empirical results show that technological, political and resource uncertainty are the most dominant sources of perceived uncertainty influencing entrepreneurial decision-making. By performing a dynamic analysis, we furthermore demonstrate that perceived uncertainties and motivation are not stable, but evolve over time. We identify critical factors in the project's internal and external environment which influence these changes in perceived uncertainties and motivation, and describe how various interactions between the different variables in the conceptual model (internal and external factors, perceived uncertainty, motivation and previous actions of the entrepreneurs) positively or negatively influence the decision of entrepreneurs to continue entrepreneurial action. We discuss how policymakers can use these insights for stimulating the development and diffusion of emerging renewable energy technologies.
\end{abstract}

(C) 2007 Elsevier Ltd. All rights reserved.

Keywords: Perceived uncertainty; Entrepreneurial action; Emerging technology

\section{Introduction}

The ever-growing body of literature on innovation and entrepreneurial decision-making reveals that there is a large and diverse set of factors influencing the decision of entrepreneurs whether or not to engage in innovation activities. These numerous factors range from characteristics of the innovation itself (e.g. the distinction between radical versus incremental innovations or the relative

\footnotetext{
${ }^{*}$ Corresponding author. Department of Innovation Studies, Copernicus Institute for Sustainable Development and Innovation, Utrecht University, PO Box 80115, 3508 TC Utrecht, The Netherlands. Tel.: + 3130253 1625; fax: +31302532746 .

E-mail address: i.meijer@geo.uu.nl (I.S.M. Meijer).
}

advantage of an innovation compared with established technologies (Dewar and Dutton, 1986; Henderson and Clark, 1990; Rogers, 1995)) to characteristics of the decision-making actor (such as personal or cultural characteristics that distinguish entrepreneurs from nonentrepreneurs or innovators from laggards (Brockhaus, 1980; Rogers, 1995; Shane, 1995)), characteristics of the environment in which the entrepreneur is operating (e.g. the stability of the market demand or the degree of competition (Porter, 1980; Teece et al., 1997)) and so on. However, independent of the type of actor, the type of innovation or the type of environment, all innovation decisions inherently involve uncertainty (Nelson and Winter, 1977; Dosi, 1982; Rosenberg, 1996; Edquist, 
1997). Therefore, uncertainty is considered a very important factor to focus on in order to gain a better understanding of innovation decisions.

The intrinsically uncertain character of innovation decisions is particularly true for innovation decisions concerning emerging technologies, i.e. technologies that are still in an early phase of development (van Merkerk and van Lente, 2005). On the one hand, the high degree of uncertainty surrounding emerging technologies signifies the large variety of opportunities that a new technology has to offer. On the other hand, though, this uncertainty poses a threat of not knowing what comes next and not being able to ex ante determine the success or failure of a technological path (Garud and Rappa, 1994). To phrase it differently, uncertainty can both create opportunities for entrepreneurs to engage in emerging technologies, as well as hamper entrepreneurs in undertaking action. Thus, the relation between uncertainty and the decision of entrepreneurs to engage in emerging technologies is very complex.

While the emergence of new technologies in general is a long and uncertain process, this appears to be particularly true for the development and diffusion of emerging renewable energy technologies (Jacobsson and Johnson, 2000). Due to the urgent problem of climate change, there is a growing need for the application of renewable energy technologies. However, despite their large environmental benefits, large-scale implementation of emerging renewable energy technologies has proven to be difficult (Jacobsson and Bergek, 2004; Raven, 2005; Negro, 2007). In 2004, the share of renewables in western countries accounted for only $5.7 \%$ of the total primary energy supply (IEA, 2007). Several authors have argued that uncertainty is one of the major barriers for the breakthrough of emerging renewable energy technologies (Kemp et al., 1998; Rotmans, 2003; Jacobsson and Bergek, 2004; Foxon et al., 2005). More specifically, Jacobsson and Bergek (2004) argue that uncertainty is blocking the development and implementation of renewable energy technologies, since it hinders the fulfilment of entrepreneurial activities (Jacobsson and Bergek, 2004). This is problematic, since the emergence of a new technology cannot take place without the involvement of entrepreneurs who dare to take action under uncertainty, in pursuit of a possible opportunity arising from the new technology (Hekkert et al., 2007). In order to contribute to a better understanding of the underlying mechanisms that determine the emergence of renewable energy technologies, this article therefore aims to provide insight into the influence of uncertainty on entrepreneurial action in emerging renewable energy technologies.

In traditional entrepreneurship literature, the success or failure of entrepreneurial action is often attributed to specific individuals who have the vision, skills and risktaking mentality needed to discover, create and exploit opportunities that lie beyond the reach of most (see Gartner (1990) for an overview). However, there is a growing awareness that the development of emerging technologies cannot be attributed to any one individual actor, but is best understood as "both an individual and a collective act" (Van de Ven, 1993; Edquist, 2001; Garud and Karnøe, 2003; Jacobsson and Bergek, 2004; Hekkert et al., 2007). As Garud and Karnøe (2003) argue, "technology entrepreneurship is a larger process that builds upon the efforts of many". According to this stream of research, entrepreneurs are not only technology-developers who produce new technologies, but, for instance, also adopters (buyers and users) who offer critical inputs for the commercialization of emerging technologies (Van de Ven, 1993; Garud and Karnøe, 2001, 2003). In this article, we subscribe to the idea that the development of emerging renewable energy technologies is the result of actions from multiple entrepreneurs. However, in contrast to the above scholars, we do not analyze the emerging technology from a macro- or system-level perspective but focus on specific innovation projects from the perspective of the various entrepreneurs involved. In this article, we focus on the development of biomass gasification technology by studying various innovation projects aimed at developing and implementing this emerging renewable energy technology. This focus on innovation projects is useful for providing more insight into the relation between entrepreneurial action and the perception of uncertainties.

This study builds on the work of McMullen and Shepherd (2006) who argue that, in order to understand the influence of perceived uncertainty on entrepreneurial action, we are required to examine not only perceived uncertainty but also the entrepreneur's motivation. They explain that whether an entrepreneur will engage in a particular action is a decision that depends on whether the entrepreneur is motivated enough to act, given the uncertainty he or she expects to encounter in pursuit of an opportunity (McMullen and Shepherd, 2006). Thus, motivation needs to outweigh perceived uncertainty in order for entrepreneurs to act. This implies that we need to analyse both perceived uncertainty as well as the balance between perceived uncertainty and motivation if we want to understand why some entrepreneurs decide to act whereas others do not.

We will make three contributions to the conceptual framework of McMullen and Shepherd (2006). First, we will break down uncertainty perceptions in different sources of uncertainty. Whereas McMullen and Shepherd (2006) analyse perceived uncertainty by looking at whether or not an entrepreneur possesses enough knowledge in order to recognize an opportunity worth pursuing, we try to specify in what domains knowledge is lacking by distinguishing between different uncertainty sources. The entrepreneurs involved in emerging technologies are confronted not only with high uncertainty about the technology itself but also with uncertainty about other elements in the socio-institutional environment in which the new technology will be embedded, such as uncertainty about unclear user requirements or the actions of competitors (Rosenberg, 1996; Afuah and Utterback, 
1997; Meijer et al., 2006). Since previous research (Meijer et al., 2007) has suggested that entrepreneurs initiate different types of activities in order to deal with different sources of perceived uncertainty, we believe that identifying dominant sources of uncertainty can deliver valuable insights for entrepreneurs and policymakers to develop strategies for better managing these uncertainties. Second, we will add a dynamic perspective. McMullen and Shepherd (2006) only focus on the initial decision of an entrepreneur to engage in entrepreneurial action. If we consider the fact that many entrepreneurial activities are stopped prematurely, then apparently an entrepreneur's decision to act is not permanent. This being true, we need to develop a more dynamic view of how perceived uncertainties and motivation, and consequently an entrepreneur's decision to act, change over time. Third, if we want to understand why some entrepreneurs decide to act whereas others do not, we need to know more about the factors that influence an entrepreneur's perception of uncertainties and motivation. Therefore, we pose the following research questions:

1. Which sources of uncertainty are perceived to be important for the decisions of the various entrepreneurs involved in development and implementation projects of biomass gasification in the Netherlands?

2. How do perceived uncertainties and motivation influence entrepreneurial action in different phases of the biomass gasification projects?

3. What are critical factors influencing the perceived uncertainties and the motivation of entrepreneurs in the biomass gasification projects?

The article proceeds as follows. In Section 2, we discuss some relevant theories on uncertainty and introduce a typology of uncertainty sources relevant for analysing entrepreneurial action regarding emerging technologies. We apply these theoretical insights in an empirical case on biomass gasification in the Netherlands (Section 4). Gasification is a very efficient technology to convert biomass into electricity. Although in the Netherlands the expectations about this emerging renewable energy technology are high, the breakthrough of this technology proves difficult since many projects, which were set up by entrepreneurs to develop and implement this technology, have failed (Green Balance, 2004; Kwant and Knoef, 2004; van Ree et al., 2005; Faaij, 2006; Negro et al., 2006). By analyzing several innovation projects over time and comparing them, we are able to answer our research questions. We end our article by discussing the main conclusions and policy implications (Section 5).

\section{Perceived uncertainty and entrepreneurial action in emerging technologies}

A useful conceptualization of uncertainty for studying uncertainty from the perspective of the entrepreneurs, originates from the organizational management literature. Within the organizational management literature, a line of research is dedicated to analyzing perceptions of uncertainty in the external environment of an organization (e.g. Duncan, 1972; Milliken, 1987; Boyd and Fulk, 1996; Dickson and Weaver, 1997; Sutcliffe and Zaheer, 1998). Frances Milliken defines uncertainty as "an individual's perceived inability to predict something accurately" (Milliken, 1987). The term 'perception' refers to the process by which individuals organize and evaluate stimuli from the environment. The existence of information itself lacks meaning until an individual perceives it (Corrêa, 1994). Environments are therefore neither certain nor uncertain but are simply perceived differently by various actors. Thus, this stream of research departs from the idea that uncertainty is objective by arguing that actors differ in their perception of uncertainty. Furthermore, the above-mentioned scholars conceptualize uncertainty as a multidimensional construct and, therefore, emphasize that it is important to identify the different sources of uncertainty which the actor is uncertain about (Duncan, 1972; Milliken, 1987; Dickson and Weaver, 1997). Following these organizational management scholars, we apply a subjective perspective on uncertainty (and therefore use the term 'perceived uncertainty') and consider perceived uncertainty as comprising of different uncertainty sources.

For decisions concerning emerging technologies, an apparent source of uncertainty is technological uncertainty, since the performance of the new technology is still unclear and many alternative designs are competing for dominance (Tushman and Rosenkopf, 1992; Rosenberg, 1996; Anderson and Tushman, 2001). However, uncertainty will arise not only about the technology itself, which still needs to be shaped, but also about the socio-institutional setting in which the emerging technology will be embedded. In this early stage, user demands are not clearly articulated and a market for the new technology still has to be created. Technology developers will perceive uncertainty about user requirements and market demand, whereas potential users will perceive uncertainty about what the new technology might have to offer (Tushman and Rosenkopf, 1992; Afuah and Utterback, 1997). In addition, current regulation is aligned with established technologies and does not always provide room for the introduction of new technologies (Jacobsson and Bergek, 2004). This creates uncertainty about which institutional regulations and support mechanisms will emerge for the new technology (Van de Ven, 1993). As a result, the actors involved in the development and implementation of emerging technologies are confronted with high uncertainties in different domains. Based on an extensive literature review and previous empirical work, which is reported in Meijer et al. (2006, 2007), we propose to distinguish between the following set of uncertainty sources for analyzing perceptions of uncertainties concerning the development and implementation of emerging technologies: technological, resource, competitive, supplier, consumer and political uncertainty (see Table 1). 
Table 1

Sources of perceived uncertainty with respect to innovation decisions

\begin{tabular}{ll}
\hline $\begin{array}{l}\text { Uncertainty } \\
\text { source }\end{array}$ & Description \\
\hline $\begin{array}{l}\text { Technological } \\
\text { uncertainty }\end{array}$ & $\begin{array}{l}\text { This source includes uncertainty about the } \\
\text { characteristics of the new technology (such as costs } \\
\text { or performance), about the relation between the new } \\
\text { technology and the technical infrastructure in which } \\
\text { the technology is embedded (uncertainty to what } \\
\text { extent adaptations to the infrastructure are needed), } \\
\text { and about the possibility of choosing alternative } \\
\text { (future) technological options. }\end{array}$
\end{tabular}

Resource This source includes both uncertainty about the uncertainty amount and availability of raw material, human and financial resources needed for the innovation, and uncertainty about how to organize the innovation process (e.g. in-house or external R\&D, technology transfer, education of personnel). Resource uncertainty resides at the level of the individual firm, as well as at the level of the innovation system.

Competitive uncertainty

Whereas technological uncertainty includes uncertainty about competing technological options, competitive uncertainty relates to uncertainty about the behavior of (potential or actual) competitors and the effects of this behavior.

Supplier Uncertainty about the actions of suppliers (i.e. uncertainty uncertainty about the reliability of the supplier), which often manifests itself as uncertainty if the supplier will live up to agreements about the timing, quality and price of the delivery. Supplier uncertainty becomes increasingly important when the dependence on a supplier is high.

Consumer Uncertainty about consumers relates to uncertainty uncertainty about consumers' preferences with respect to the new technology, about the compatibility of the new technology with consumers' characteristics ${ }^{\mathrm{a}}$ and, in general, uncertainty about the long-term development of the demand over time.

Political Political uncertainty comprises uncertainty about uncertainty governmental behavior, regimes, and policies. Not only changes in policy, but also ambiguity in interpretation of current policy or a lack of policy can lead to uncertainty. Another important cause for political uncertainty is unpredictability of governmental behavior.

\footnotetext{
${ }^{\text {a}}$ For example, an important consumers' characteristic for energy
} technologies is the energy demand.

The effect of uncertainty on innovation has been the subject of many studies. A distinction can be made between studies that focus on uncertainty in relation to the development of new products and studies that analyze the effect of uncertainty on the adoption of new technologies. In the new product development literature, much attention has been paid to analyzing the effect of uncertainty on the development process and on the success of new products (e.g. Griffin and Hauser, 1996; Mullins and Sutherland, 1998; Souder et al., 1998; Bstieler and Gross, 2003). The aim of most of these studies is to determine which strategies (in terms of different ap- proaches to scan potential markets, distinctive levels of $\mathrm{R} \& \mathrm{D} /$ market integration or different learning strategies) are most effective in reducing the uncertainties encountered in new product development. The adoption studies, in turn, have developed important insights into the optimal timing problem of adopting a new technology under uncertainty by modelling the dilemma that firms face when having to weigh the costs of adopting too soon ('sunk costs' which cannot be recovered) against the opportunity cost of waiting in anticipation of better future technologies (e.g. Marra et al., 2003; Doraszelski, 2004), (Mamer and McCardle, 1987; Saha et al., 1994; Farzin et al., 1998). One of the outcomes of these studies is that, even though new technologies might be superior to the established technologies, firms are very cautious to adopt new technologies because of the various uncertainties they perceive (Farzin et al., 1998).

However, these studies do not provide sufficient insight in order to understand the role of uncertainties in emerging renewable energy technologies. Namely, a shortcoming of these studies is that they mainly focus on individual firms who are either developing or adopting a new technological product. Before an emerging energy technology has become so mature that it can be sold as a 'turn-key' energy plant, the technology very often enters the market as a first-of-a-kind product, consisting of different components that were never before integrated (Williams and Edge, 1996). In many cases, the technology needs to be adapted to the specific circumstances at the location of application (such as the available feedstock). In this early phase of technology development, both knowledge of the technology and knowledge of the adopting firm are needed to develop a successful working energy plant. The user of such a 'first-of-a-kind' energy plant, the adopter, therefore has a very influential role in the learning experiences with the emerging energy technology. As a result, in most adoption processes of emergent energy technologies there exists a very close interaction between the adopter and the technology developer (producer). Previous studies on uncertainty and innovation do not provide sufficient insight into the influence of uncertainty on innovation projects in which technology development and adoption are to a large extent intertwined. In addition, most of these studies evaluate which strategies are most effective in dealing with uncertainty (e.g. market research helps to reduce uncertainty about consumer demands (Mamer and McCardle, 1987; Mullins and Sutherland, 1998)), but little attention is paid to providing explanations for the fact that in some cases firms decide to act entrepreneurially by engaging in the development of an emerging technology, whereas in other cases they do not. In this article, we aim to address these under-analysed topics.

To do so, we build on a recent article by McMullen and Shepherd (2006) on entrepreneurial action and the role of uncertainty in theories of entrepreneurship in which they explain that one cannot understand the decision of entrepreneurs whether or not to act under uncertainty 


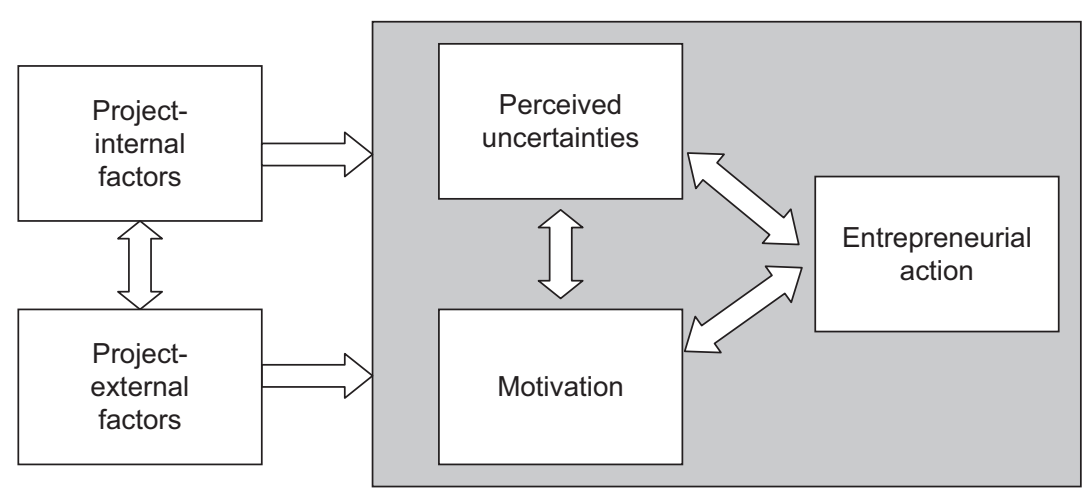

Fig. 1. A conceptual model describing entrepreneurial action under perceived uncertainty.

without taking into account the entrepreneur's motivation. They explain that "entrepreneurs respond to and create change through their entrepreneurial actions, where entrepreneurial action refers to behaviour in response to a judgemental decision under uncertainty about a possible opportunity for profit" (McMullen and Shepherd, 2006, p. 134). They argue that whether an entrepreneur will engage in a particular action (e.g. engage in the development and implementation of an emerging technology) is a decision that depends on whether the entrepreneur is motivated enough to act, given the uncertainty he or she expects to encounter in pursuit of an opportunity arising from the emerging technology. (McMullen and Shepherd, 2006) Thus, motivation needs to outweigh perceived uncertainty in order for entrepreneurs to act. This implies that, in order to understand the relation between entrepreneurial action and uncertainty, we are required to examine both perceived uncertainty and the balance between perceived uncertainty and motivation (see inner core of Fig. 1).

Although the conceptual work of McMullen and Shepherd (2006) provides a useful basis for understanding the role of perceived uncertainty on entrepreneurial action, little sense is given to the underlying factors that influence an entrepreneur's perception of uncertainty and motivation to bear uncertainty. The decisions of entrepreneurs to engage in innovation projects aimed at developing and implementing an emerging energy technology do not take place in a vacuum, but are influenced by the context in which these decisions are made. Factors in the internal and external project environment can greatly affect the entrepreneur's perception of uncertainties and/or his motivation to take action. If we want to understand why some entrepreneurs decide to act whereas others do not, we need to extend the conceptual model by identifying the critical factors in the internal or external project environment which influence the perceived uncertainties or motivation of entrepreneurs (see left-hand side of Fig. 1). ${ }^{1}$

\footnotetext{
${ }^{1}$ Note that the aim of this paper is not to analyze all factors influencing the innovation decisions of entrepreneurs, but only to identify those factors that greatly affect the entrepreneur's perceived uncertainty and/or motivation. That is why the internal and external factors are located in the 'outer area' of the conceptual model (see Fig. 1).
}

Another shortcoming of the framework of McMullen and Shepherd (2006) is that it only describes the initial decision of an entrepreneur to engage in a particular action. If we consider the fact that many entrepreneurial activities are stopped prematurely, then apparently entrepreneurs do not make this judgement once but constantly reassess their decision. Perceived uncertainties and motivation will not be stable, but will evolve over time under the influence of previous actions, changes in the internal or external factors and so on. Therefore, we claim that a dynamic analysis is needed in order to understand when and why this balance between perceived uncertainty and motivation changes.

\section{Methodology}

In this article, we apply our ideas on perceived uncertainty and entrepreneurial action to the empirical case of stand-alone biomass gasification in the Netherlands. ${ }^{2}$ For this case study, we examined seven innovation projects aimed at the development and implementation of biomass gasification. In order to perform a dynamic analysis, we collected data on various project phases: the start-up phase, the implementation phase and the exploitation phase. The start-up phase ends when the construction of the plant starts; the implementation phase ends when the gasification plant is operational. From the total population of Dutch biomass gasification projects (including both terminated and ongoing projects, both small-scale projects of $1-5 \mathrm{MW}_{\mathrm{e}}$ and large-scale projects of $20 \mathrm{MW}_{\mathrm{e}}$ or more), we studied all four projects that have reached the implementation or exploitation phase as well as three projects that were abandoned in the start-up phase. ${ }^{3}$ An overview of the projects included in our case study is given in Fig. 2.

\footnotetext{
${ }^{2}$ This case focuses on biomass gasification plants where only biomass is gasified; combined gasification of coal and biomass is not included.

${ }^{3} \mathrm{We}$ tried to include all projects that were terminated in the start-up phase. However, the total number of projects that have been abandoned in the start-up phase is not exactly known, as not all companies report on these projects. Furthermore, we were not always able to conduct an interview on these projects, since interviewees had difficulty to recall projects which terminated quickly after the start.
} 


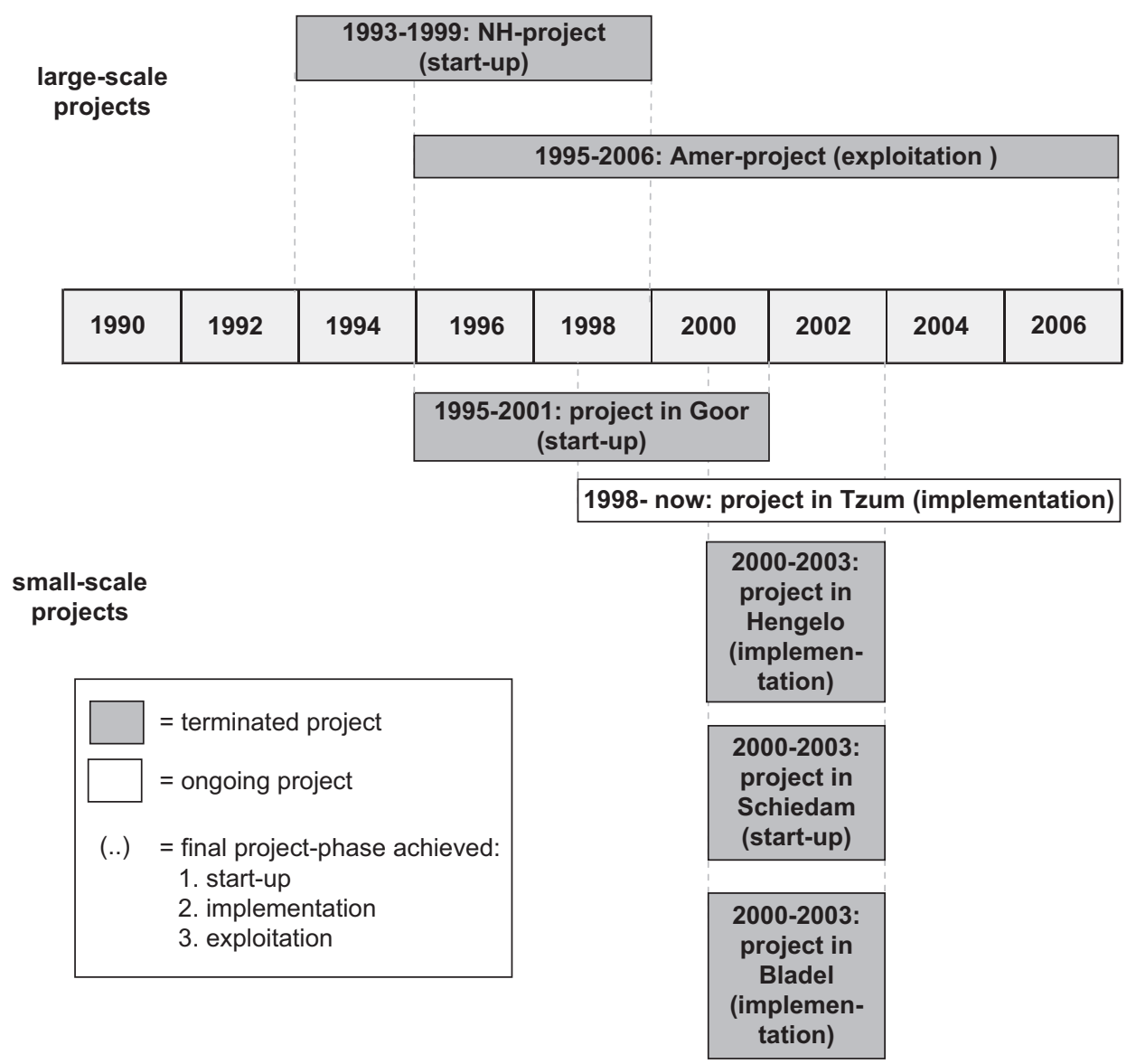

Fig. 2. Timeline of studied projects.

Data were collected by conducting 16 interviews. We mostly interviewed technology developers (suppliers of gasification technology) and adopters (buyers and users of gasification technology, such as energy companies, farmers or waste-processing companies), as these parties fulfilled the role of entrepreneur in the biomass gasification projects. ${ }^{4}$ We aimed at conducting more than one interview for each project, in order to include differences in perceptions between the various entrepreneurs involved and to triangulate the data of the different interviews. In addition to the interviews with the entrepreneurs, we conducted some interviews with researchers and governmental authorities who have a broad overview of the developments in the Netherlands.

The advantage of interviews is that information can be gathered on perceptions and strategies of actors, which is difficult to attain from other sources. However, the drawback of interviews is that selective or biased answers can be given. This is especially the case for interviews about historical events (such as projects that took place several

\footnotetext{
${ }^{4}$ The entrepreneurs that we refer to in this case study are firms (rather than individuals). Of these firms, we interviewed those employees who have been directly involved in the decision-making process.
}

years ago). In order to avoid this drawback as much as possible and improve the reliability and validity of the data, we combined information from the interviews with information from other data sources (data triangulation). Prior to the interview, we studied various types of documents (policy documents, scientific articles, project reports, professional journals and newspaper articles) to identify the key events in which the interviewee had been involved. During the first part of the interviews, we used these key events in order to help the interviewee recall specific situations in order to reconstruct the project's storyline. Using this storyline, the second part of the interviews focused on identifying the entrepreneurs' motivations, perceptions of uncertainties, decisions on whether or not to continue and the actions that followed from these decisions for different phases of the project. Perceptions of uncertainty were identified by using open questions in which the interviewees had to describe their perceptions (independent of our typology of uncertainty sources) as well as closed questions in which the interviewees had to rank each of the uncertainty sources according to the level of uncertainty and the relative importance in relation to the other uncertainty sources. After the interviews, we used various types of documents to verify and complete the data from the interviews. 


\section{Biomass gasification in the Netherlands}

Producing energy out of biomass is seen as one of the key options to mitigate greenhouse gas emissions and substitute fossil fuels (Faaij, 2006). Biomass materials that can be used for energy production are very diverse, ranging from food crops and forest products (such as wood thinning or straw) to waste streams as demolition wood or chicken manure. Gasification is a thermo-chemical process technology, which converts biomass into a combustible gas (called 'producer gas' or 'syngas') (Den Uil et al., 2004). ${ }^{5}$ The produced gas (consisting mainly of $\mathrm{CO}$ and $\mathrm{H}_{2}$ ) can be burned for heat or steam supply, or it can be used in secondary conversion technologies such as gas turbines and engines for producing electricity or mechanical work. ${ }^{6}$ The advantage of gasification is that much higher electrical efficiencies can be reached (35-40\%) compared with combustion power plants (25-30\%) (Williams and Larson, 1996; Faaij et al., 1997). However, gasification is technologically much more complex. Although this emerging technology can make a substantial contribution to the achievement of a renewable energy system, realization of biomass gasification projects often proves difficult and only a few projects in Europe have achieved a commercial status (Kwant and Knoef, 2004; Faaij, 2006). In the Netherlands, entrepreneurs have initiated numerous activities to develop and implement this technology, but many of these activities have been abandoned (Green Balance, 2004; van Ree et al., 2005; Negro et al., 2006). Below, we analyze what role perceived uncertainties have played in this.

\subsection{Dominant uncertainty sources}

In Section 2, we introduced a typology of uncertainty sources with respect to innovation decisions of entrepreneurs. In order to analyze what uncertainty sources played a dominant role in the development and implementation of biomass gasification, we asked the interviewees which uncertainties they perceived as dominant for their decisions regarding biomass gasification and classified their answers according to our typology of uncertainty sources (see Table 2). ${ }^{7}$ As Table 2 shows, technological uncertainty, political uncertainty and resource uncertainty were mentioned far more often than the other uncertainty sources and therefore can be considered most important in innovation decisions.

Arguments for the importance of uncertainty about the technology itself were the lack of previous experiences with

\footnotetext{
${ }^{5}$ This is achieved through the partial combustion of the biomass material in a restricted supply of air or oxygen in a high-temperature environment.

${ }^{6}$ The producer gas can be used not only to produce energy, but also as feedstock for chemical processes in order to produce, for example, liquid biofuels. In this article, we focus on the application of biomass gasification for energy production.

${ }^{7} \mathrm{We}$ asked this question in 12 of the 15 interviews.
}

the technology that created uncertainty about the performance of biomass gasification plants. Also, the time needed to make the technology actually work was often mentioned to cause uncertainty.

The first argument why political uncertainty was so important was related to uncertainty about the licensing procedure and emission regulation. In order to build a biomass gasification plant, a license needs to be obtained in which specific rules (including emission norms) are laid down. In the Netherlands, the licensing procedure of bioenergy projects is very complex and ambiguous, takes very long and offers many opportunities for neighboring people and environmentalists to object to the license (Van Ree et al., 2000; Lindeman, 2004; Gerlagh and Lammers, 2006). As a result, the interviewees perceived great uncertainty about the duration and outcome of the licensing procedure since delays of the procedure or imposition of strict emission rules can have serious consequences for the profitability of a project. The second argument for the importance of political uncertainty was that the majority of the interviewees $(58 \%)$ perceived uncertainty about the financial instruments for renewable energy in general. The financial subsidy that entrepreneurs received from the government for the production of renewable electricity has been forming an important incentive for entrepreneurs to initiate biomass gasification projects (Kwast, 2006; Van Dongen, 2006). However, the financial instruments of the Dutch government changed frequently and often unexpectedly over the past years. In 2003, a year later than the government initially announced, the fiscal support for renewable electricity (i.e. renewable electricity was exempted from the national energy tax, $\mathrm{REB}^{8}$ ) was replaced by the non-fiscal MEP-levy ${ }^{9}$ that subsidizes the production of renewable electricity in the Netherlands (Kwant and Knoef, 2004). In subsequent years, the Dutch government has implemented several adaptations to the MEP instrument, which were not announced beforehand. As a result, the uncertainty that entrepreneurs perceive about changes in the financial instruments of the Dutch government has been one of the most important aspects hindering the development and implementation of biomass gasification (Green Balance, 2004; Gerlagh and Lammers, 2006). The frequent and often unexpected changes of the financial instruments in the past resulted in perceived uncertainty not only about future changes of these instruments but also about the reliability of the Dutch government in general.

Arguments for the importance of resource uncertainty were first of all related to the market for biomass. This market is relatively new and unstable, and since the demand for biomass (especially wood) has been exceeding the supply, the entrepreneurs perceived uncertainty about the availability, quality and price of biomass (Gerlagh and Lammers, 2006; Schouwenberg, 2006). In addition, the

\footnotetext{
${ }^{8} \mathrm{REB}=$ Regulerende EnergieBelasting (regulating energy tax).

${ }^{9} \mathrm{MEP}=$ regeling Milieukwaliteit ElektriciteitsProductie (environmental quality of electricity production).
} 
Table 2

General overview of the uncertainties that are perceived as dominant

\begin{tabular}{|c|c|c|c|}
\hline Uncertainty source & Examples mentioned by interviewees $(n=12)$ & Number of interviewees & $\%$ of interviewees \\
\hline \multirow[t]{4}{*}{ Technological } & Uncertainty about the technology itself & 11 & 92 \\
\hline & Uncertainty about the choice between different technological alternatives & 2 & 17 \\
\hline & Number of other examples mentioned by only 1 interviewee & 0 & 0 \\
\hline & Total number of examples for technological uncertainty & 13 & \\
\hline \multirow[t]{4}{*}{ Political } & Uncertainty about the licensing procedure and emission regulation & 8 & 67 \\
\hline & Uncertainty about financial instruments (REB, MEP) & 7 & 58 \\
\hline & Number of other examples mentioned by only 1 interviewee & 6 & 50 \\
\hline & Total number of examples for political uncertainty & 21 & \\
\hline \multirow[t]{4}{*}{ Resource } & Uncertainty about biomass resources & 5 & 42 \\
\hline & Uncertainty about financial resources & 5 & 42 \\
\hline & Number of other examples mentioned by only 1 interviewee & 2 & 17 \\
\hline & Total number of examples for resource uncertainty & 12 & \\
\hline \multirow[t]{4}{*}{ Supplier } & Uncertainty about the reliability of technology suppliers & 1 & 8 \\
\hline & Uncertainty about the reliability of biomass suppliers & 1 & 8 \\
\hline & Number of other examples mentioned by only 1 interviewee & 0 & 0 \\
\hline & Total number of examples for supplier uncertainty & 2 & \\
\hline \multirow[t]{2}{*}{ Competitive } & Number of examples mentioned by only 1 interviewee & 0 & 0 \\
\hline & Total number of examples for competitive uncertainty & 0 & \\
\hline \multirow[t]{3}{*}{ Consumer } & Uncertainty about the consumers of the produced electricity & 2 & 17 \\
\hline & Number of other examples mentioned by only 1 interviewee & 0 & 0 \\
\hline & Total number of examples for consumer uncertainty & 2 & \\
\hline
\end{tabular}

entrepreneurs were uncertain about financial resources. Due to the early stage of development, it is uncertain if and when the costs of an investment in biomass gasification can be recovered. The interviewees perceived uncertainty about the mobilization of financial resources both within the firm and external to the firm (from banks or other investors).

Thus, the results from Table 2 show that perceived uncertainty is not a one-dimensional concept, but that major sources of perceived uncertainty can be identified. For biomass gasification, the dominant sources of perceived uncertainty influencing entrepreneurial decision-making are technological, political and resource uncertainty. Since these three uncertainty sources are mentioned far more often than the other uncertainty sources, the results of Table 2 display a rather robust view. However, if we look back at the timeline of projects in Fig. 2, this static analysis of uncertainty sources does not explain why some entrepreneurs decide to terminate their innovation projects whereas others continue. Therefore, we need to zoom in on the dynamics of the innovation projects.

\subsection{Dynamic project analysis}

In this section, we describe seven projects aimed at developing and implementing biomass gasification in the Netherlands (see Fig. 2). Since biomass gasification technology is not yet so mature that it can be bought 'from the shelf', all these projects can be classified as 'firstof-a-kind' projects in which technology development and adoption are to a large extent intertwined. For each project, we analyze how the entrepreneurs' perceptions of uncertainties, their motivations to engage in the innovation project and their decisions whether or not to act evolve over time. We describe not only the decisions of entrepreneurs but also the actions that follow from these decisions. Namely, the actions that entrepreneurs undertake can subsequently lead to changes in perceived uncertainties or motivation. Furthermore, we look for internal and external factors in the project environment influencing entrepreneurs' perceived uncertainties and motivations. We classified the projects according to the final phase achieved (start-up, implementation and exploitation). ${ }^{10}$

\subsubsection{The start-up phase}

4.2.1.1. NH project. In 1993, the Province ${ }^{11}$ of NorthHolland, together with the local energy companies PEN and UNA, ${ }^{12}$ the $\mathrm{SEP}^{13}$ and $\mathrm{ECN}^{14}$ announced to build the first large-scale biomass gasification plant in the Netherlands. The Province of North-Holland initiated and

\footnotetext{
${ }^{10}$ For the terminated projects, the last phase achieved is the phase in which the project has been abandoned; for the ongoing projects, this is the current phase.

${ }^{11}$ The Province is the regional level of government in the Netherlands.

${ }^{12}$ After the liberalization of the energy market, energy companies PEN and UNA were taken over by ENW.

${ }^{13}$ The SEP was the coordinating organization of the national energy companies.

${ }^{14} \mathrm{ECN}=$ Energy Research Centre of the Netherlands.
} 
coordinated the project, driven by their ambition to provide an energy supply system that was affordable, reliable and sustainable (De Boer, 2005; Daey Ouwens, 2005). At the start of the project, the entrepreneurs involved perceived uncertainty about the availability and price of biomass and about the technology, since biomass gasification was not yet a proven technology and the project members differed in opinion about which technological configuration was best and which technology supplier to select (Stuurgroep project Biomassavergassing Noord-Holland, 1999; De Boer, 2005; Daey Ouwens, 2005; Van Dongen, 2006). Different perceptions of uncertainties by the project partners led to cooperation and coordination problems in the project consortium. Failed attempts to cooperate with the local waste-processing company delayed the project even more (De Boer, 2005; Daey Ouwens, 2005). Meanwhile, the institutional context in which the project was taking place was changing drastically due to the liberalization of the Dutch energy market (which was initiated in 1998). One of the results of the liberalization was that the energy companies became competitors and no longer cooperated in realization of high-risk environmental-friendly projects. Instead, their attention shifted towards lowering production costs and making low-risk investments in other domains than sustainable energy R\&D (Raven, 2006). Because the start-up phase was taking longer than expected, these changes in the institutional context (an 'external factor', see Fig. 2) started to interfere with the project. While the final investment decision was still not made, the energy companies involved became increasingly reluctant to invest in such a high-risk project (De Boer, 2005; Daey Ouwens, 2005; Van Dongen, 2006). Since the Province could not undertake the project without the involvement of the energy companies (being the adopters of the technology), this posed a serious threat to the project (De Boer, 2005; Daey Ouwens, 2005). In 1998, the entrepreneurs collectively decided to abort their plans (Stuurgroep project Biomassavergassing Noord-Holland, 1999). As the entrepreneurs involved themselves indicated, this decision was influenced by a combination of perceived uncertainties and diminished motivation (De Boer, 2005; Daey Ouwens, 2005; Van Dongen, 2006). The many delays of the project, and the changes in the institutional setting which occurred during this long time period, reduced the motivation of the entrepreneurs. Adding to this explanation was that the actor constitution (an 'internal factor', see Fig. 2) had been too complex as the various entrepreneurs involved were too diverse in order to collectively undertake this project. The involvement of multiple entrepreneurs in a project increases the chance that the perceptions of uncertainty and the motivation to engage in the project diverge among the various entrepreneurs involved. Since the lack of a common understanding can hamper fruitful cooperation in multi-actor projects (e.g. Koppenjan, 2005), diverging perceptions and motivations increase the risk of project abortion.
4.2.1.2. Project in Goor. In 1995, technology developer BTG, energy company Edon and wood-processing company Bruins \& Kwast jointly initiated the plan to implement a small-scale gasification plant in Goor. Edon and BTG had both been involved in an EU-sponsored R\&D project on fixed-bed gasification of biomass which had been evaluated positively, and therefore decided to continue their activities with this technology by starting an implementation project (Knoef, 2006). Wood-processing company Bruins \& Kwast decided to engage in the project because of the opportunities that this high-efficient technology had to offer for the conversion of wood residues into energy (Kwast, 2006). At the start of the project, the main sources of perceived uncertainty were technological uncertainty and political uncertainty (uncertainty about the licensing procedure) (Knoef, 2006; Kwast, 2006). Because the project team thought that these perceived uncertainties could be reduced, these uncertainties did not form a barrier (Knoef, 2006). However, just as in the $\mathrm{NH}$ project, changes in the institutional context interfered with the project. Due to the liberalisation of the energy market, the constitution of actors involved in the project changed as energy company Edon was taken over by Essent. As a result, the project proposal had to be reapproved by Essent's board of directors. However, because Essent did not have much faith in small-scale gasification, Essent's motivation to engage in the project did not outweigh the perceived uncertainties. As a result, the project was cancelled (Green Balance, 2004; Knoef, 2006; Kwast, 2006).

Like in the $\mathrm{NH}$ project, this project shows that institutional change (an 'external' factor) can negatively influence the decision of entrepreneurs to engage in innovation projects. Furthermore, this project shows that the entry of a new player (e.g. change of the actor constitution; an 'internal' factor) can have a major impact on the continuation of an innovation project as new players might be less willing to bear perceived uncertainties than the actors who initiated the project. This is in line with the findings of Van de Ven et al. (1999), who show that changes in management can have disruptive effects on innovation projects that received a lot of support from the previous management team.

4.2.1.3. Project in Schiedam. In 2000, technology developer BTG and energy company ONS decided to install a biomass gasification plant at the site of ONS in Schiedam. For BTG, the project offered the opportunity to install two gasifier units, which had already been built and tested, in a real-life situation so as to learn how the technology would perform. Energy company ONS was mainly interested in the implementation of these biomass gasifier units in order to produce renewable electricity. (Tijmensen and De Vos, 2005; Knoef, 2006) From the start of the project, technological uncertainty, resource uncertainty (i.e. uncertainty about knowledge, financial resources and biomass resources) and political uncertainty were perceived to be 
high (Knoef, 2006). Since two different gasifier units would have to be coupled together, technological uncertainty was higher compared with other small-scale gasification projects. Despite the high perceived uncertainties, the project team was fully committed to the project since they believed in the opportunity of implementing the available gasifier units (Knoef, 2006). After years of preparation, the project team presented the project proposal to the board of directors of ONS. In contrast to the project team, the gasification project was but one of a set of business plans that the board of directors had to consider. The board of directors rejected the plan as they perceived the investment risks of the gasification project too high (Green Balance, 2004; Knoef, 2006). The project team attempted to reduce the risks by reducing the scale of the project to one gasifier unit instead of two, which would lower the technological complexity and costs of the project. Nevertheless, the board of directors also turned down the renewed proposal and the project was terminated. Again, a collective entrepreneurial project was terminated because the adopter of the technology retreated. Similar to the project in Goor, this project showed that the involvement of a new actor (i.e. a change in the actor constitution; an 'internal factor') can lead to the termination of an innovation project. In this project, the entrepreneurs who initiated the project (the members of the project team) were overruled by top managers who were less willing to tolerate perceived uncertainties. This problem is frequently encountered in innovation projects. Van de Ven and colleagues explain it as such: "Whereas the innovation may be the exclusive labour of love for the innovation team, it is but one of a set of interacting, often competing, business considerations for top managers and investors" (Van de Ven et al., 1999, pp. 58-59).

\subsubsection{The implementation phase}

4.2.2.1. Project in Bladel. The small-scale gasification project in Bladel was initiated by a farmer, Mr. Duis. For farmers, biomass gasification promised to be an attractive solution for the disposal of manure. Due to the increase in livestock and the strict manure disposal regulation, the costs for manure disposal were high. By implementing a gasification plant to convert manure into energy, manure disposal costs could be saved (Buffinga and Knoef, 2001; Duis, 2006). In 2000, Mr. Duis contacted technology developer BTG, and the project was started. One of the first uncertainties that the entrepreneurs encountered was uncertainty about the licensing procedure. The entrepreneurs perceived uncertainty if they would obtain a license for gasification of chicken manure, since the existing manure legislation did not provide for the application of this new technology for manure disposal (Duis, 2006). In reaction to this uncertainty, Mr. Duis tried to gain support from the local authorities who were responsible for the licensing procedure. After many conversations, the authorities exempted the project from the manure legislation and granted a temporarily license for a trial period of 3 years. (Duis, 2006) The entrepreneurs believed that this 3-year period would be sufficient to develop a successful working plant and to obtain a permanent license (by showing that the operational plant would comply with the emission rules) (Knoef, 2006). A second important source of perceived uncertainty was technological uncertainty, since biomass gasification was not yet a 'proven' technology (Duis, 2006; Knoef, 2006). However, this uncertainty did not form a barrier since both entrepreneurs were eager to make the installation work. Construction of the plant was soon started. Unfortunately, the first tests were unsuccessful and revealed several technological problems. In order to solve these problems and thereby reduce technological uncertainty, the entrepreneurs jointly worked on improving the technology by 'trial-and-error' learning (Duis, 2006; Knoef, 2006). Although the entrepreneurs were making progress, the entrepreneurs still perceived uncertainty about how to solve the remaining technological problems. In addition to this technological uncertainty, uncertainty arose about the reliability of the supplier of one of the technological components who delivered a poorly working product and did not live up to the agreements (Duis, 2006; Knoef, 2006). When the supplier even went bankrupt, Mr. Duis decided to develop the component itself (Duis, 2006). Thus, in contrast to the projects that were terminated in the startup phase, the motivation of the adopter of the technology (Mr. Duis) was extremely high. Nevertheless, as a result of the unanticipated problems, the project was running out of budget and uncertainty about how to mobilise additional financial resources needed to proceed with the project increased. BTG and Mr. Duis had already invested significant time and money in the project, but the installation was still not operational and the period of validity of the temporary license was coming to an end. In addition to the negative influence of the limited temporal duration (an 'internal' factor), changes in the economic conditions (i.e. an 'external factor') occurred and negatively influenced the motivation to engage in the project (Knoef, 2006). Due to an outbreak of avian influenza among poultry in 2002, many Dutch farmers went out of business. As a result, the high costs for manure disposal rapidly declined and the economic incentive for undertaking the project disappeared. The entrepreneurs reconsidered their actions and decided to stop. They could have decided to continue their biomass gasification activities, but then they had to again apply for a temporary license and mobilise additional financial resources. While technological uncertainty and resource uncertainty had increased in comparison to the start of the project, the motivation to cope with these perceived uncertainties had diminished as the expected outcomes of the project were no longer feasible, considering the limited time left, nor attractive under the changed economic circumstances.

4.2.2.2. Project in Hengelo. In 2000, technology developer HoSt approached waste-processing company Twence 
and wood chip supplier Bruins \& Kwast in order to collectively implement a small-scale fixed-bed gasifier at the site of Twence in Hengelo. Twence and Bruins \& Kwast decided to engage in the project, since both companies were interested in the opportunities that this high-efficient technology had to offer for the conversion of wood residues into energy (Kwast, 2006; Rooijakkers and Dijkman, 2006). The project received a temporary license for a trial-period of 3 years (De Kant, 2006). In the start-up phase, technological uncertainty was perceived to be the most important uncertainty source. The entrepreneurs realized that the development and implementation of a successful working biomass gasification plant involved many technological uncertainties because biomass gasification was still a new and 'unproven' technology. Nevertheless, the entrepreneurs believed that they would be able to overcome technological uncertainties within the available time (De Kant, 2006; Kwast, 2006; Rooijakkers and Dijkman, 2006). However, during the implementation phase, the entrepreneurs perceived growing technological uncertainty since technological problems were more severe than expected. After some years of experimenting, the entrepreneurs had not yet been able to develop a successful working plant and the costs of the project were running high. Thus, technological uncertainty was accompanied by perceived uncertainty about how to mobilise additional financial resources that were needed to proceed with the project. At this point in time, the limited temporal duration of the project (a project internal factor) started to interfere, as the validity duration of the license was coming to an end, while the entrepreneurs still had not been able to reduce perceived uncertainty concerning if and how they could solve the technological problems. Similar to the project in Bladel, the limited time span that remained to turn the project into a success made the entrepreneurs involved re-evaluate their actions. Because of the increase of resource uncertainty and technological uncertainty, the entrepreneurs decided to abort the project (De Kant, 2006; Kwast, 2006; Rooijakkers and Dijkman, 2006). For technology developer HoSt, the decision to stop was also influenced by external technological developments (an 'external factor'). HoSt could have decided to continue with the development of the technology by applying for a new license and finding new investment partners. However, due to the disappointing results of this project in comparison to the good results of HoSt's activities in the development and implementation of competing technologies (e.g. fluidized-bed gasification, combustion and digestion), HoSt's faith in the potential of fixed-bed gasification had diminished over the years (De Kant, 2006). Thus, for HoSt, the decision to stop was a combination of increased perceived uncertainties and diminished motivation.

4.2.2.3. Project in Tzum. The project in Tzum is currently the only ongoing biomass gasification project in the Netherlands (see Fig. 2). Just like the project in Bladel, the small-scale gasification project at the farm of Mr. Atsma in Tzum was initiated to find a solution for the high costs of manure disposal (Tijmensen and De Vos, 2005; De Kant, 2006; Dijkstra, 2006). The project was supported by a cooperation of farmers in the north of the Netherlands. ${ }^{15}$ Technology developer HoSt delivered the fluidized-bed gasifier. ${ }^{16}$ From the start of the project in 1998, uncertainty about the mobilization of financial resources has been playing a dominant role. The subsidy that the project acquired from the government was insufficient to cover all the costs (Dijkstra, 2006). More than once, investors decided to withdraw their proposal to finance the project due to the uncertainties they perceived about the functioning of this new technology and about the financial governmental support (MEP instrument) (De Kant, 2006; Dijkstra, 2006). In addition, one of the investors went bankrupt and the farmers themselves came into financial problems due to the outbreak of the avian influenza in 2002 (an 'external factor'). As a result, the project encountered large delays and the entrepreneurs perceived great uncertainty of whether they would be able to mobilize the financial resources that were needed to build the gasifier (De Kant, 2006; Dijkstra, 2006). Despite the setbacks, the entrepreneurs held on to their plans and searched for new investors. Their persistence had not been in vain, since energy company Eneco finally decided to supply the necessary funds to start the construction of the gasifier (De Kant, 2006). In January 2006, construction work was finished and testing of the installation began. At the time of the interview (June 2006), the installation was still not fully operational. Since the budget of the project is still limited, uncertainty about the mobilization of additional financial resources remains important for the continuation of the project (De Kant, 2006; Dijkstra, 2006). However, in contrast to the projects in Bladel and Hengelo, expectations about the outcome of the project are still high and the entrepreneurs expect that, once the installation performs well, it will be easier to acquire additional funds to go on with the project (De Kant, 2006). Besides, the barrier to abandon the project is high because the entrepreneurs have already invested a lot of time and money which would be lost if they decided to stop. As a result, the entrepreneurs are extremely motivated and continue investing in order to make good on prior investments, thereby accepting high levels of perceived uncertainties. This is a typical example of 'entrapment' or 'escalating commitment' (Brockner and Rubin, 1985; Brockner, 1992;

\footnotetext{
${ }^{15}$ To support this project, the SBNN (Stichting Biomassavergassing Noord Nederland, Foundation for Biomass gasification North-Netherlands) has been established. Besides the farmers, a cooperation of forestry managers who is interested in gasification of wood thinning is participating in this foundation.

${ }^{16} \mathrm{HoSt}$ had previously stopped their activities with fixed-bed gasifiers (see description of the Hengelo project), but continued their work on the development of fluidized-bed gasifiers.
} 
Ross and Staw, 1993). One of the project team members explained it as such:

We have made enormous investments, so if we would quit now we would lose a lot of money. There is no way back. Besides, we have good prospects for scaling-up our activities since many farmers have shown interest in the technology. (De Kant, 2006)

Thus, the positive expectations about the outcome of the project, in combination with the feeling of entrapment from past investments, motivate the entrepreneurs to continue and bear perceived uncertainties. ${ }^{17}$

\subsubsection{The exploitation phase}

4.2.3.1. Amer project. The Amer project was one of the first biomass gasification projects in the Netherlands and has been the only project that has reached the exploitation phase (see Fig. 2). In 1995, several energy companies (PNEM, NUON and EPZ) together with biomass supplier BFI launched the plan to build a large-scale gasifier near the existing coal-fired power plant 'Amercentrale' in order to contribute to $\mathrm{CO}_{2}$-emission reduction policy of the Dutch government (EPZ 1995). In this period (see Fig. 2), the energy sector had very high expectations about biomass gasification and technological uncertainty was perceived to be low (Van Buijtenen, 2006; Negro, 2007). Biomass gasification would merely be a new combination of technologies, which were already proven in the application of coal gasification. Shortly after the start of the project, BFI decided to withdraw from the project because it was more profitable to export the demolition wood to Scandinavia than to use it for gasification in the Amer project. As a result of this change in actor constitution (an 'internal factor'), the remaining entrepreneurs perceived uncertainty about the availability and price of biomass and decided to put the project on hold (Energie- en Milieuspectrum, 1996; Duurzame Energie, 1996; Willeboer, 2005). After some months, the energy companies managed to close a long-term contract with another wood supplier and the project was restarted. A German technology developer was selected to build the gasifier. Although the technology developer had never before built a gasification plant for fuels other than coal, the technology developer was very confident about its competences to develop and implement a wood gasifier. The technology developer sold the gasification plant as a commercial unit and gave guarantees about the availability of the plant (in terms of the frequency and duration of outages due to maintenance or technological failures) (Willeboer, 2005). In 1999, all contracts were signed and construction of the plant began. ${ }^{18}$

\footnotetext{
${ }^{17} \mathrm{~A}$ few months after the interview (October 2006), we learned that the project in Tzum has managed to enter the exploitation phase.

${ }^{18}$ The liberalization of the Dutch energy market in 1998 did not influence the Amer project, since the investment decision had already been made and Essent (successor of EPZ and PNEM) did not change course (Willeboer, 2005).
}

When commissioning activities started, many technical problems arose and stable operation of the plant was impossible (Essent Energie BV, 2001; Willeboer 2005). Biomass gasification turned out to be more complicated than expected since the process characteristics were completely different compared with coal gasification. Several modifications were needed to solve the problems. Energy company Essent (the successor of EPZ and PNEM) realized that technological uncertainties had been heavily underestimated since the technology was far from commercially viable (Willeboer, 2005). As a result of the disappointing performance of the installation and the difficulty the technology developer had to solve the technical problems, Essent not only perceived technological uncertainty but also perceived uncertainty about the reliability of the technology developer (supplier uncertainty) (Willeboer, 2005). However, since already a lot of time and money had been invested, the barrier to abandon the project was much higher than in the start-up phase (Willeboer, 2005). In order to make good on prior investments, Essent became extremely motivated to continue with the project ('entrapment'). As a result, Essent was willing to bear perceived uncertainties that they would not have accepted earlier on in the project when investments were still modest. In order to solve the technical problems, Essent became actively involved in the technology-development process. In this way, Essent was able to gain technical knowledge and hands-on experience and thereby to reduce technological uncertainty. This knowledge base, in turn, enabled Essent to take over the maintenance and operation of the plant and terminate the contract with the German technology developer, thereby eliminating supplier uncertainty. In 2005, the gasification plant was finally operational and the project entered the exploitation phase.

This project is probably the clearest example that the time needed for the development and implementation of biomass gasification is often underestimated. Instead of 4 months, 7 years were needed to make the installation function properly! However, in contrast to the projects in Bladel and Hengelo, the setbacks that occurred radically changed the perceived uncertainties and expectations not only in this project but also in the sector at large. Because the Amer project was the first large-scale biomass gasification project in the Netherlands that had reached the implementation phase, the project had a large exposure. The severe problems of the Amer project, in combination with the bad experience from unsuccessful implementation projects abroad, made people in the whole sector realize that expectations had been overly optimistic and uncertainties heavily underestimated (Van Buijtenen, 2006; Van der Drift, 2006). Uncertainty about the performance of biomass gasification technology increased and actors became more reluctant to invest in large-scale biomass gasification projects (Van Dongen, 2006; Negro, 2007). To illustrate this, we point out that the diminished faith in biomass gasification technology was one of the main 
reasons for energy company Nuon to abort the plan to build a biomass gasification installation near one of their power plants ('Hemweg-8 centrale') (Van Dongen, 2006). Moreover, banks became unwilling to issue loans for such high-risk projects in biomass gasification (Van Dongen, 2006).

Because of the disappointing results, it is even more surprising that the Amer project was not terminated during the implementation phase. This underlines the perseverance and commitment of the adopter to make the project successful and to cope with perceived uncertainties. Unfortunately, uncertainties did not disappear when the Amer project reached the exploitation phase. Even though technological uncertainty had finally decreased, there was an increase in political uncertainty. The reason for this was that the government had announced a new emission law (i.e. institutional change, an 'external factor'). The effect of this new law was that not only the gasifier itself but also the coal-fired power plant in which the syngas was cocombusted would fall into the category of waste-disposal companies. Since waste-disposal companies had to comply with very strict emission rules, the biomass gasification project would no longer be economically feasible under the new emission law (Willeboer, 2005; Schouwenberg, 2006). Thus, the new emission law made no provision for an exceptional case like the Amer project. ${ }^{19}$ Essent approached the government in order to raise awareness for the problem and to request a solution. The government promised to solve the problem by exempting the Amer project from the emission law. However, $1 \frac{1}{2}$ years later, Essent was still waiting for the official exemption and, as a result, perceived ever-growing uncertainty if the government would live up to its promise (Willeboer, 2005). When, in December 2005, the new law came into force, the Amer project still had not received an exemption. Since Essent still had hope while uncertainty about the exemption continued to exist, the introduction of the new law put an end to both uncertainty and hope. After all the efforts that had been made to make the gasification plant operational, the gasifier was shut down. (Schouwenberg, 2006; Van den Brand, 2006) Governmental policy had changed from being an incentive to start the project into the death-blow that stopped the project.

Thus, the termination of this project was not the result of perceived uncertainty, but of the disruptive effect of the new law on the entrepreneur's motivation to continue biomass gasification activities. Nevertheless, this incident has led to an increase of perceived uncertainty in another manner: since the government had not been able to keep its promise about the exemption, Essent perceives uncertainty

\footnotetext{
${ }^{19}$ The Amer project was an exceptional case, since the combination of a wood gasifier and a conventional power plant did not exist elsewhere. In the Amer project, 'non-clean' contaminated biomass (demolition wood) is converted into 'clean' syngas, which is co-combusted in the existing power plant. The license obtained in 1998 permitted this exceptional situation, but the BVA made no provision for a transformation of 'non-clean' to 'clean' fuel and only looked at the 'non-clean' input of the gasifier.
}

about the reliability of the government as an important barrier to new investments in innovative renewable energy projects (Willeboer, 2005; Schouwenberg, 2006). ${ }^{20}$

\subsection{Towards a dynamic view of entrepreneurial action under perceived uncertainties}

Analyzing the above project descriptions helps us to gain a deeper understanding of the complex relation between perceived uncertainties, motivation and the decision of entrepreneurs to take action. First of all, the project descriptions supported the argument of McMullen and Shepherd (2006), put forward in Section 2, which whether or not an entrepreneur decides to act is dependent not only on the perceived uncertainties but also on the entrepreneur's motivation. In all projects, we observed that the decision to initiate the project was based on the recognition of an opportunity arising from the emerging technology (e.g. technology developers discovered opportunities for making profit out of selling biomass gasification plants, whereas adopters of the technology saw opportunities for making profit by selling the renewable energy produced with biomass gasification). These positive expectations about the potential rewards of the project initially formed a strong motivation for the entrepreneurs to bear perceived uncertainties.

Another result of the dynamic project analysis is that it revealed that the decision of entrepreneurs to act is not a permanent decision, but rather one that is constantly reassessed. The project descriptions clearly showed that perceived uncertainties and motivation are not stable, but change over time. At the start of the biomass gasification projects, we noticed that motivation of the entrepreneurs was high enough to encounter perceived uncertainties. However, in most of the projects, this initial balance between motivation and perceived uncertainties changed over time. Entrepreneurs abandoned their projects because motivation had declined and/or perceived uncertainties had increased. These changes in motivation and perceived uncertainties can have several causes. Below, we describe how various factors in the internal and external project environment may influence the perceived uncertainties and motivation of entrepreneurs.

\subsubsection{Critical factors in the internal and external project environment}

Our empirical results demonstrated that the perception of uncertainty and motivation are influenced by various project internal factors (see Fig. 3). One of the project internal factors that played an important role in the biomass gasification projects was the constitution of actors involved in the projects. Since actors have different frames

\footnotetext{
${ }^{20}$ Essent is investigating if they can restart the Amer project with clean biomass material, but this would mean that additional modifications have to be made to the gasifier. (Schouwenberg, 2006)
} 


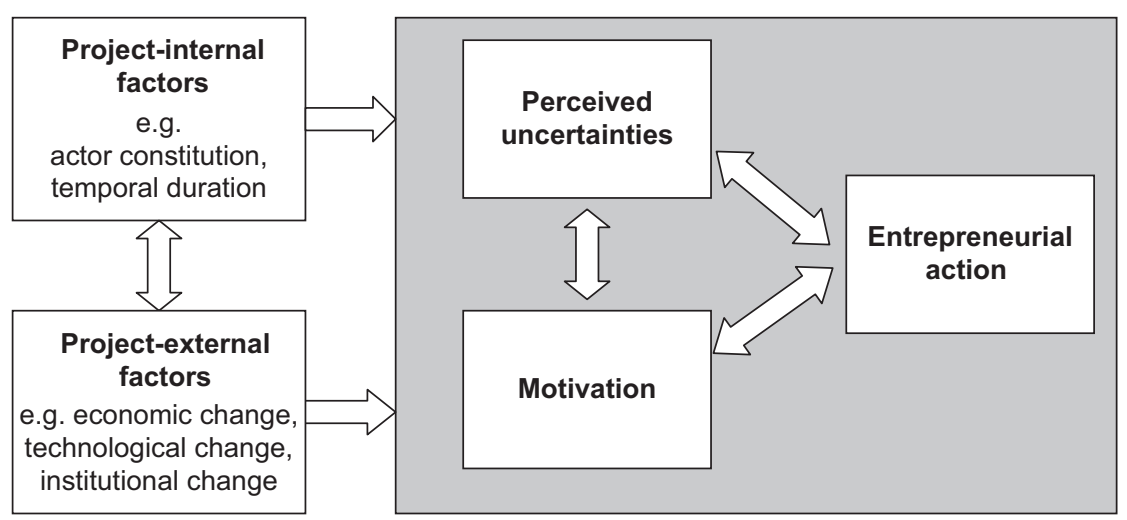

Fig. 3. Conceptual model relating entrepreneurial action to perceived uncertainties, motivation and various internal and external factors.

of reference, motives to engage in the project, experiences and skills, they will also differ in their perception of uncertainty and reaction to uncertainty. As the $\mathrm{NH}$ project showed, the involvement of multiple entrepreneurs in a project increases the chance that the perceptions of uncertainty and the motivation to engage in the project diverge among the various entrepreneurs involved. Since the lack of a common understanding can hamper fruitful cooperation in multi-actor projects (e.g. Koppenjan, 2005), diverging perceptions and motivations increase the risk of project abortion. Furthermore, the constitution of actors involved in an innovation project is not necessarily stable (Garud and Karnøe, 2003; Koppenjan and Klijn, 2004). Actors can enter or exit the project and the roles that actors play within the project can alter over time. The projects in Goor and Schiedam showed that the entrance of a new actor who is less willing to bear perceived uncertainties can have serious consequences for the continuation of an innovation project.

Another example of a project internal factor that played an influential role in the biomass gasification projects was the temporal duration of the project. The time and financial resources that are available to turn an innovation project into a success are limited. The projects in Bladel and Hengelo showed that this is often underestimated. The projects in Bladel and Hengelo both received a temporary license for a period of 3 years, which was supposed to be sufficient to develop a successful working plant. Due to the limited time scale of the project, the entrepreneurs were forced to re-evaluate their actions when the validity period of the license was coming to an end. The entrepreneurs realized that they were unable to reduce uncertainty about how to solve the remaining technological problems and uncertainty about how to mobilize additional financial resources within the limited time they had still left. They decided to abandon their projects instead of trying to obtain a new license in order to continue their biomass gasification activities. Thus, the limited temporal duration of the project negatively reinforced the perceived uncertainties and motivation of the entrepreneurs to continue with the project. The Amer project, on the contrary, did not have a limited time scale. Although the Amer project encountered just as much technological problems as the projects in Bladel and Hengelo, the entrepreneur of the Amer project managed to develop a successful working plant after 7 difficult years. If the entrepreneur would have faced a hard deadline within this 7-year period, he might as well have decided to stop. Since there was no deadline, the entrepreneur was able to continue experimenting with the technology and thereby to reduce technological uncertainty. However, the temporal duration of a project can also play a role in projects which do not encounter a hard deadline. For example, in the $\mathrm{NH}$ project, the long delays led to a loss of 'momentum' and to declining motivation of the entrepreneurs involved.

Apart from project internal factors, the project descriptions showed that several factors in the external environment of a project influence the perceptions of uncertainties and motivation of entrepreneurs (see Fig. 3). For example, economic change (e.g. changes in the market prices) can influence the expected profits of the project. This was clearly visible in the project in Bladel, which was initiated to avoid high manure disposal costs. Due to an outbreak of avian influenza, the manure disposal costs decreased and therefore the expected savings, which the project would yield, diminished. Since the economic incentive to engage in the project had vanished, the motivation of the entrepreneur decreased.

The project descriptions furthermore showed that external technological developments can greatly affect the entrepreneurs' motivation and perceptions of uncertainty. In the Hengelo project, we noticed that perceived technological uncertainty increased and expectations about the outcome of the biomass gasification project (and thereby the motivation to engage in the project) decreased due to successful developments of competitive technologies. The sector-wide effects of the technological failures in the Amer project illustrated that not only developments of competitive technologies but also developments of competitive projects with identical technologies can influence how entrepreneurs perceive and respond to uncertainties. Due to the failures of the Amer project, entrepreneurs of other 
biomass gasification projects became more uncertain about the technology and, in several cases, even abandoned their activities.

Another example of an external factor, which we observed in the biomass gasification projects, was institutional change. Institutions (such as regulation, standards and so on) guide actors' perceptions and actions (Edquist, 1997; Geels, 2004). Institutional change can therefore greatly influence how entrepreneurs perceive and respond to uncertainties. In the empirical case, the $\mathrm{NH}$ project and the project in Goor were influenced by the liberalisation of the energy market. The liberalization drastically affected the goals and management strategies of the energy companies, since energy companies became competitors and no longer cooperated in the realization of high-risk environmental-friendly projects (Raven, 2006). As a result of this institutional change, the incentive for energy companies to engage in a biomass gasification project and the willingness to bear perceived uncertainties had diminished.

In a similar manner, various other internal and external factors may influence the perception of uncertainties and motivation of the entrepreneurs and, consequently, the decision whether or not to act. What makes it even more complex is that different interaction patterns may occur between the variables in the model (see Fig. 3).

\subsubsection{Interaction patterns}

When analyzing the biomass gasification projects, we observed that many of the abandoned projects can be characterized by the occurrence of negative interaction patterns, where internal factors, external factors and perceived uncertainties interact and reinforce each other in a negative way. One of the negative interaction patterns that we observed in the project descriptions was the interaction between temporal duration (a project internal factor) and institutional change (a project external factor). The long duration of a project increases the chance that changes in external factors occur. For instance, if the $\mathrm{NH}$ project would not have been delayed (like in the Amer project, which started approximately at the same time), the investment decision would already have been made before the liberalization of the energy market started to interfere with the investment decisions of the energy companies. In a similar manner, we observed that changes in external factors can reinforce changes in internal factors. To illustrate, in the project in Goor the liberalization of the energy market (external factor) resulted in a change in the actor constitution (internal factor), which in turn resulted in re-evaluation and termination of the project.

Apart from interactions between the internal and external factors, different sources of perceived uncertainty can reinforce each other in a negative manner. For example, several investors decided to withdraw their proposal to finance the project in Tzum due to the uncertainties they perceived about the performance of this emerging energy technology and about the financial support from the government. As a result, entrepreneurs became uncertain about the mobilization of financial resources and the project was seriously delayed. This negative interaction pattern between technological uncertainty and resource uncertainty was also visible in the sector at large. Due to the poor results of the Amer project and various projects abroad, perceived uncertainty about the performance of biomass gasification technology increased in the sector as a whole. This technological uncertainty made banks reluctant to invest in biomass gasification projects. As a result, entrepreneurs became uncertain about the mobilization of financial resources and decided to postpone or cancel their projects. Thus, negative technological developments external to the project may lead to an increase of perceived technological uncertainty, which in turn may lead to an increase of perceived uncertainty about resources and thereby to a slowing down or termination of the innovation project. In the same manner, other negative interaction patterns can develop and hamper entrepreneurial action.

Luckily, not all interaction patterns have a negative influence on the continuation of entrepreneurial action. The project descriptions illustrated that the decision whether or not to continue entrepreneurial action can be positively influenced by previous actions of the entrepreneur. The project descriptions showed that, if an entrepreneur is motivated to take action under perceived uncertainties, the entrepreneur will initiate all sorts of activities in order to reduce the major sources of perceived uncertainty. For example, in the Bladel project, the entrepreneur initiated a dialogue with the local governmental authorities who were responsible for the licensing procedure in order to gain support for the project. By involving governmental authorities, the entrepreneur managed to reduce political uncertainty. In reaction to uncertainty about the mobilization of biomass resources (Amer project) or financial resources (project in Tzum), we noticed that entrepreneurs aimed at cooperation with biomass suppliers and external investment partners, respectively. In both the Bladel and the Amer projects, we observed that the entrepreneurs actively engaged in technology-development activities in order to build-up technological know-how and become independent of technology suppliers. Thus, experimenting with the technology helped to reduce technological uncertainty and uncertainty about the reliability of technology suppliers. As was shown in the Amer project, this reduction of perceived uncertainties, in turn, may stimulate the entrepreneur to continue entrepreneurial action. Thus, if entrepreneurial action results in a reduction of perceived uncertainties, which reinforces the entrepreneur's motivation and finally leads to continuation of entrepreneurial action, we speak of a positive interaction pattern.

The type of interaction patterns that arise are highly context-specific and can differ in each phase of the project. For instance, in the start-up phase of the Amer project, the entrepreneur was not motivated enough to cope with 
uncertainty about the availability and price of biomass resources and decided to put the project on hold. In this phase of the project, investments were still modest and the consequences of delaying or terminating the project were small. However, as investments mounted during the implementation phase, so did the barrier to abandon the project. In order to make good on prior investments, the entrepreneur was extremely motivated to turn the project into a success. As a result of this 'entrapment' situation, the entrepreneur was far more willing to cope with perceived uncertainties than in the start-up phase. Instead of deciding to delay or stop the project, the entrepreneur decided to initiate all sorts of activities to reduce the major sources of uncertainty. A positive interaction pattern of continued entrepreneurial action and decreasing perceived uncertainties was build-up. This positive interaction pattern abruptly ended in the exploitation phase due to the negative influence of an external factor (the introduction of a new emission law).

Thus, the effect that perceived uncertainties have on entrepreneurial action is complicated by the large diversity of internal and external factors and the complex interdependencies between the various variables in the conceptual model (see Fig. 3). A dynamic analysis, which aims at identifying these internal and external factors and analysing the different interaction patterns, is needed in order to better understand why and how perceived uncertainties, motivation and the decision of whether or not to act evolve over time.

\section{Conclusions and policy implications}

The aim of this article was to gain a deeper understanding of the role of perceived uncertainties in innovation projects aimed at developing and implementing emerging renewable energy technologies. Previous researchers have often argued that the emergence of a new technology is inherently uncertain and that this uncertainty can block entrepreneurial action. In this article, we wanted to take this argument a step further by identifying the major sources of perceived uncertainty and analyzing how perceived uncertainty influences entrepreneurial action in different phases of an innovation project. From the empirical case on the development and implementation of biomass gasification in the Netherlands, we conclude that the dominant uncertainty sources influencing entrepreneurial decisionmaking in this early stage of technological development are technological, political and resource uncertainty.

Furthermore, our empirical analysis supports the argument of McMullen and Shepherd (2006) that the decision of an entrepreneur whether or not to engage in a particular action is dependent on the balance between perceived uncertainty and motivation. Entrepreneurs will decide to act only if they are motivated enough, given the uncertainty they expect to encounter in pursuit of an opportunity. However, we believe that the work of McMullen and Shepherd (2006) has some important limitations in that it only focuses on the initial decision of entrepreneurs to undertake a particular action and does not provide explanations for the fact that many innovation projects are abandoned prematurely. By performing a dynamic analysis, we were able to examine how perceived uncertainties and motivation change over time and how these changes affect the decision of entrepreneurs whether or not to continue their actions. This dynamic analysis showed that many biomass gasification projects have been abandoned before ever reaching the exploitation phase because perceived uncertainties increased and motivation decreased over time. Such changes in perceived uncertainties and motivation are influenced by various factors in the project's internal environment, such as changes in the actor constitution or the temporal duration of the project, and factors in the external environment of the project, like economic change, institutional change or technological developments external to the project. By showing how various negative and positive interaction patterns can occur between these internal and external factors and the entrepreneurs' perceived uncertainties and motivation, we provide a deeper insight into the underlying dynamics of innovation projects.

Given the increasing interest in understanding and steering entrepreneurial activities within sustainable technology development (e.g. Jacobsson and Bergek, 2004; Elzen et al., 2004; Elzen and Wieczorek, 2005; Raven, 2006; Negro, 2007), we believe that both scholars and policymakers may benefit from this more dynamic perspective on the role of perceived uncertainties in entrepreneurial action. The conceptual framework that we applied in our empirical case provides policymakers three different options in order to reduce the negative consequences of perceived uncertainties on entrepreneurial action: policy can directly address the sources of uncertainty, policy can influence the motivation of the entrepreneurs and policy can aim at decreasing the negative influence of factors in the project's environment. Using the empirical case on biomass gasification as an example, the following policy recommendations can be made. First of all, policy instruments can be aimed at directly reducing perceived uncertainties. Although some of the uncertainty sources (such as technological uncertainty or supplier uncertainty) lie beyond the direct control of policymakers, policymakers play an important role in reducing political uncertainty. Since our empirical analysis showed that political uncertainty is one of the major sources of uncertainty for the entrepreneurs involved in biomass gasification projects, reducing this uncertainty can form an important stimulus for entrepreneurial action. With respect to biomass gasification, the main issues are to reduce the ambiguity and complexity in the emission regulation concerning the license of bio-energy plants ${ }^{21}$ and to reduce uncertainty

\footnotetext{
${ }^{21}$ Although the Dutch government is aware of the fact that the emission regulation and license procedure forms an important source of uncertainty and is trying to solve the problems, their activities have not yet been sufficient to remove this uncertainty.
} 
about future changes of the financial instruments. Second, policy instruments can be aimed at increasing the motivation of entrepreneurs to engage in biomass gasification projects. As we described in the empirical section, the governmental subsidy that entrepreneurs receive for producing renewable electricity has formed an important incentive to engage in bio-energy projects. However, the effectiveness of these financial instruments in terms of increasing the motivation of entrepreneurs is counteracted by the uncertainty which entrepreneurs perceive with respect to the frequent and unexpected changes of these instruments. Third, policy instruments can be aimed at protecting first-of-a-kind projects like the biomass gasification projects from the negative influences of factors in the project's environment. With respect to the biomass gasification projects, one of the ways for policymakers to do this is to grant a first-of-a-kind project a permanent license instead of a temporary license for a limited trial period. By preventing the fact that the limited validity duration of licenses becomes a barrier, entrepreneurs have more time to learn how best to deal with the perceived uncertainties they encounter in the development and implementation of emerging technologies. Another way to help entrepreneurs of these first-of-a-kind projects is to provide risk capital. As was illustrated in the case study, entrepreneurs often have difficulty to mobilize financial resources since banks, investors or top management are reluctant to invest in high-risk projects aimed at implementing emerging technologies that are not yet 'proven'. By making more governmental funds available for these first-of-a-kind projects, the projects will become less vulnerable to the judgements of above-mentioned parties and uncertainty about the mobilization of financial resources will be reduced. In order for emerging renewable energy technologies to develop into 'proven' and widely diffused technologies, it is essential that several of these "first-of-a-kind" projects manage to succeed. Therefore, policymakers should use all the options they have in order to support entrepreneurs to cope with the large uncertainties, which are encountered in "first-of-a-kind" projects, and thereby to prevent that so many of these projects fail.

\section{Acknowledgements}

This article is part of the research project 'Managing uncertainties in energy innovations and transition processes', financially supported by NWO (Dutch Organization for Scientific Research), KSI (the Dutch Knowledge network on System Innovations and transitions) and CATO (Dutch knowledge network in the field of $\mathrm{CO}_{2}$ Capture and Storage). The authors would like to thank Simona Negro for providing an extensive literature overview of the development of biomass gasification in the Netherlands. The authors are especially grateful to the interviewees for their willingness to participate and for their valuable contributions, which have formed the empirical foundation of this article. Furthermore, the authors would like to thank the participants of the SPRU 40th Anniversary Conference (Brighton, September 2006) and two anonymous reviewers of Energy Policy for their useful comments on earlier versions of this article.

\section{References}

Afuah, A.N., Utterback, J.M., 1997. Responding to structural industry changes: a technological evolution perspective. Industrial and Corporate Change 6, 183-202.

Anderson, P., Tushman, M.L., 2001. Organizational environments and industry exit: the effects of uncertainty, munificence and complexity. Industrial and Corporate Change 10 (3), 675-710.

Boyd, B.K., Fulk, J., 1996. Executive scanning and perceived uncertainty: a multidimensional model. Journal of Management 22 (1), 1-21.

Brockhaus Sr., R.H., 1980. Risk taking propensity of entrepreneurs. The Academy of Management Journal 23 (3), 509-520.

Brockner, J., 1992. The escalation of commitment to a failing course of action-toward theoretical progress. Academy of Management Review 17 (1), 39-61.

Brockner, J., Rubin, J.Z., 1985. Entrapment in Escalating Conflicts: A Social Psychological Analysis. Springer, New York.

Bstieler, L., Gross, C.W., 2003. Measuring the effect of environmental uncertainty on process activities, project team characteristics, and new product success. Journal of Business and Industrial Marketing 18 (2-3), 146-161.

Buffinga, G.J., Knoef, H.A.M., 2001. Implementation and Demonstration of an Embedded Small-scale Poultry Manure CHP Process. Biomass Technology Group (BTG).

Corrêa, H.L., 1994. Linking Flexibility, Uncertainty and Variability in Manufacturing Systems: Managing Un-planned Change in the Automtative Industry. Avebury, Aldershot.

Daey Ouwens, C., 2005. Interview with Professor Daey Ouwens (TU Eindhoven, formerly Province of North-Holland). Utrecht.

De Boer, G., 2005. Interview with Mr. De Boer (formerly Province of North-Holland). Vijfhuizen.

De Kant, E., 2006. Interview with Mr. De Kant (HoSt). Hengelo.

Den Uil, H., Van Ree, R., et al., 2004. Duurzaam synthesegas: Een brug naar een duurzame energie- en grondstoffenvoorziening, ECN Biomassa.

Dewar, R.D., Dutton, J.E., 1986. The adoption of radical and incremental innovations: an empirical analysis. Management Science 32 (11), 1422-1433.

Dickson, P.H., Weaver, K.M., 1997. Environmental determinants and individual-level moderators of alliance use. Academy of Management Journal 40 (2), 404-425.

Dijkstra, J.L., 2006. Interview with Mr. Dijkstra (Stichting Biomassavergassing Noord Nederland, SBNN). Burgum.

Doraszelski, U., 2004. Innovations, improvements, and the optimal adoption of new technologies. Journal of Economic Dynamics \& Control 28 (7), 1461-1480.

Dosi, G., 1982. Technological paradigms and technological trajectories: a suggested interpretation of the determinants and directions of technical change. Research Policy 11, 147-162.

Duis, W., 2006. Interview with Mr Duis (Duis V.O.F.). Bladel.

Duncan, R.B., 1972. Characteristics of organizational environments and perceived uncertainty. Administrative Science Quarterly 17 (3) 313-327.

Duurzame Energie, 1996. Vergassingsproject Amercentrale niet haalbaar. Duurzame Energie 4, 40.

Edquist, C. (Ed.), 1997. Systems of Innovation; Technologies, Institutions and Organizations. Science, Technology and the International Political Economy Series. Pinter, London.

Edquist, C., 2001. Innovation systems and innovation policy: the state of the art. Invited Paper for DRUID's Nelson-Winter Conference, Aalborg, Denmark. 
Elzen, B., Geels, F.W., et al., 2004. System Innovation and the Transition to Sustainability. Edward Elgar Publishing, Cheltenham, UK.

Elzen, B., Wieczorek, A., 2005. Transitions towards sustainability through system innovation. Technological Forecasting and Social Change 72 (6), 651-661.

Energie- en Milieuspectrum, 1996. Kolencentrales onderzoeken import hout. Energie- en Milieuspectrum, pp. 14-19.

EPZ, 1995. Startnotitie bouw vergassingsinstallatie op het Amercentralecomplex te Geertruidenberg.

Essent Energie BV, 2001. Co-combustion of gasified contaminated waste wood in a coal fired power plant; public report to the EU. Essent Energie BV, Geertruidenberg.

Faaij, A.P.C., 2006. Bio-energy in Europe: changing technology choices. Energy Policy 34 (3), 322-342.

Faaij, A., van Ree, R., et al., 1997. Gasification of biomass wastes and residues for electricity production. Biomass and Bioenergy 12 (6), 387-407.

Farzin, Y.H., Huisman, K.J.M., et al., 1998. Optimal timing of technology adoption. Journal of Economic Dynamics and Control 22 (5), 779-799.

Foxon, T.J., Gross, R., et al., 2005. UK innovation systems for new and renewable energy technologies: drivers, barriers and systems failures. Energy Policy 33 (16), 2123-2137.

Gartner, W.B., 1990. What are we talking about when we talk about entrepreneurship? Journal of Business Venturing 5 (1), 15-28.

Garud, R., Karnøe, P., 2001. Path creation as a process of mindful deviation. In: Garud, R., Karnøe, P. (Eds.), Mahwah, Path Dependence and Creation. Lawrence Erlbaum Associates, New Jersey, pp. 1-38.

Garud, R., Karnøe, P., 2003. Bricolage versus breakthrough: distributed and embedded agency in technology entrepreneurship. Research Policy 32 (2), 277-300.

Garud, R., Rappa, M.A., 1994. A sociocognitive model of technology evolution - the case of cochlear implants. Organization Science 5 (3), 344-362.

Geels, F.W., 2004. From sectoral systems of innovation to socio-technical systems - insights about dynamics and change from sociology and institutional theory. Research Policy 33 (6-7), 897-920.

Gerlagh, T., Lammers, E., 2006. Actieplan Biomassa: inhoudelijk eindrapport, SenterNovem.

Green Balance, 2004. Evaluatie Gestopte Kleinschalige bio-energie Projecten. DEN, SenterNovem.

Griffin, A., Hauser, J.R., 1996. Integrating R\&D and marketing: a review and analysis of the literature. Journal of Product Innovation Management 13 (3), 191-215.

Hekkert, M.P., Suurs, R.A.A., et al., 2007. Functions of innovation systems: a new approach for analysing technological change. Technological Forecasting and Social Change 74 (4), 413-432.

Henderson, R.M., Clark, K.B., 1990. Architectural innovation: the reconfiguration of existing product technologies and the failure of established firms. Administrative Science Quarterly 35 (1), 9-30.

IEA, 2007. Renewables in global energy supply. An IEA Fact Sheet, International Energy Agency.

Jacobsson, S., Bergek, A., 2004. Transforming the energy sector: the evolution of technological systems in renewable energy technology. Industrial and Corporate Change 13 (5), 815-849.

Jacobsson, S., Johnson, A., 2000. The diffusion of renewable energy technology: an analytical framework and key issues for research. Energy Policy 28 (9), 625-640.

Kemp, R., Schot, J., et al., 1998. Regime shifts to sustainability through processes of niche formation: the approach of strategic niche management. Technology Analysis \& Strategic Management 10 (2), 175-195.

Knoef, H., 2006. Interview with Mr. Knoef (Biomass Technology Group, BTG). Enschede.

Koppenjan, J.F.M., 2005. The formation of public-private partnerships: lessons from nine transport infrastructure projects in the Netherlands. Public Administration 83 (1), 135-157.
Koppenjan, J.F.M., Klijn, E.H., 2004. Managing Uncertainties in Networks. Routledge, London.

Kwant, K.W., Knoef, H., 2004. Status of Biomass Gasification in countries participating in the IEA Bioenergy Task 33 Biomass Gasification and EU Gasnet.

Kwast, H., 2006. Interview with Mr. Kwast (Bruins \& Kwast). Goor.

Lindeman, J.H.W., 2004. Bio-energie in Nederland: monitoring vergunningverlenging 2004. Actieplan Biomassa. SenterNovem, KEMA.

Mamer, J.W., McCardle, K.F., 1987. Uncertainty, competition and the adoption of new technology. Management Science 33 (2), 161-177.

Marra, M., Pannell, D.J., et al., 2003. The economics of risk, uncertainty and learning in the adoption of new agricultural technologies: where are we on the learning curve? Agricultural Systems 75 (2-3), 215-234.

McMullen, J.S., Shepherd, D.A., 2006. Entrepreneurial action and the role of uncertainty in the theory of the entrepreneur. Academy of Management Review 31 (1), 132-152.

Meijer, I.S.M., Hekkert, M.P., et al., 2006. Perceived uncertainties regarding socio-technological transformation: towards a framework. International Journal of Foresight and Innovation Policy 2 (2), 214-240.

Meijer, I.S.M., Hekkert, M.P., et al., 2007. How perceived uncertainties influence transitions; the case of micro-CHP in the Netherlands. Technological Forecasting and Social Change 74 (4), 519-537.

Milliken, F., 1987. Three types of perceived uncertainty about the environment: state, effect, and response uncertainty. The Academy of Management Review 12 (1), 133-143.

Mullins, J.W., Sutherland, D.J., 1998. New product development in rapidly changing markets: an exploratory study. Journal of Product Innovation Management 15 (3), 224-236.

Negro, S.O., 2007. Dynamics of Technological Innovation Systems; The Case of Biomass Energy. Copernicus Institute for Sustainable Development and Innovation, Utrecht University, Utrecht.

Negro, S.O., Suurs, R.A.A., et al., 2006. The bumpy road of biomass gasification in the Netherlands: explaining the rise and fall of an emerging innovation system. Technological Forecasting and Social Change, corrected proof, in press doi:10.1016/j.techfore.2006.08.006.

Nelson, R.R., Winter, S.G., 1977. In search of useful theory of innovation. Research Policy 6 (1), 36-76.

Porter, M.E., 1980. Competitive Strategy: Techniques for Analyzing Industries and Competitors. Free Press, New York.

Raven, R.P.J.M., 2005. Strategic Niche Management for Biomass; A Comparative Study on the Experimental Introduction of Bioenergy Technologies in the Netherlands and Denmark. Department of Technology Management, Technische Universiteit, Eindhoven.

Raven, R.P.J.M., 2006. Towards alternative trajectories? Reconfigurations in the Dutch electricity regime. Research Policy 35 (4), 581-595.

Rogers, E.M., 1995. Diffusion of Innovations. Free Press, New York.

Rooijakkers, J., Dijkman, G., 2006. Interview met dhr. Rooijakkers en dhr. Dijkman (Twence). Hengelo.

Rosenberg, N., 1996. Uncertainty and technological change. In: Landau, R., Taylor, T., Wright, G. (Eds.), The Mosaic of Economic Growth. Stanford University Press, Stanford.

Ross, J., Staw, B.M., 1993. Organizational escalation and exit-lessons from the Shoreham Nuclear-Power-Plant. Academy of Management Journal 36 (4), 701-732.

Rotmans, J., 2003. Transitiemanagement: sleutel voor een duurzame samenleving. Koninklijke Van Gorcum, Assen.

Saha, A., Love, H.A., et al., 1994. Adoption of emerging technologies under output uncertainty. American Journal of Agricultural Economics 76 (4), 836-846.

Schouwenberg, P.-P., 2006. Interview with Mr Schouwenberg (Essent). Den Bosch.

Shane, S., 1995. Uncertainty avoidance and the preference for innovation championing roles. Journal of International Business Studies 26 (1), $47-68$. 
Souder, W.E., Sherman, J.D., et al., 1998. Environmental uncertainty, organizational integration, and new product development effectiveness: a test of contingency theory. Journal of Product Innovation Management 15 (6), 520-533.

Stuurgroep project Biomassavergassing Noord-Holland, 1999. Eindverslag van de Stuurgroep betreffende het project Biomassavergassing in Noord-Holland.

Sutcliffe, K.M., Zaheer, A., 1998. Uncertainty in the transaction environment: an empirical test. Strategic Management Journal 19 (1), $1-23$.

Teece, D.J., Pisano, G., et al., 1997. Dynamic capabilities and strategic management. Strategic Management Journal 18 (7), 509-533.

Tijmensen, M., De Vos, R., 2005. Bio-energie van eigen bodem. SenterNovem, Ecofys.

Tushman, M.L., Rosenkopf, L., 1992. Organizational determinants of technical change: towards a sociology of technological evolution. Research in Organizational Behavior 14, 311-347.

Van Buijtenen, J., 2006. Interview with Professor Van Buijtenen (TU Delft, formerly worked at Stork). Delft.

Van den Brand, P., 2006. EU-richtlijn nekt houtvergasser Essent. Stromen 6, 1.
Van der Drift, B., 2006. Interview with Mr. Van der Drift (ECN Biomassa). Petten.

Van de Ven, A.H., 1993. The development of an infrastructure for entrepreneurship. Journal of Business Venturing 8 (3), 211-230.

Van de Ven, A.H., Polley, D.E., et al., 1999. The Innovation Journey. Oxford University Press, New York.

Van Dongen, A., 2006. Interview with Mr. Van Dongen (Nuon, formerly UNA). Utrecht.

van Merkerk, R.O., van Lente, H., 2005. Tracing emerging irreversibilities in emerging technologies: the case of nanotubes. Technological Forecasting and Social Change 72 (9), 1094-1111.

Van Ree, R., Gerlagh, T., et al., 2000. Kritische succesfactoren biomassa, ECN.

van Ree, R., Beekes, M.L., et al., 2005. Kennisoverdracht Actieplan Biomassa, ECN Biomassa.

Willeboer, W., 2005. Interview with Mr. Willeboer (Essent). Geertruidenberg.

Williams, R., Edge, D., 1996. The social shaping of technology. Research Policy 25 (6), 865-899.

Williams, R.H., Larson, E.D., 1996. Biomass gasifier gas turbine power generating technology. Biomass and Bioenergy 10 (2-3), 149-166. 